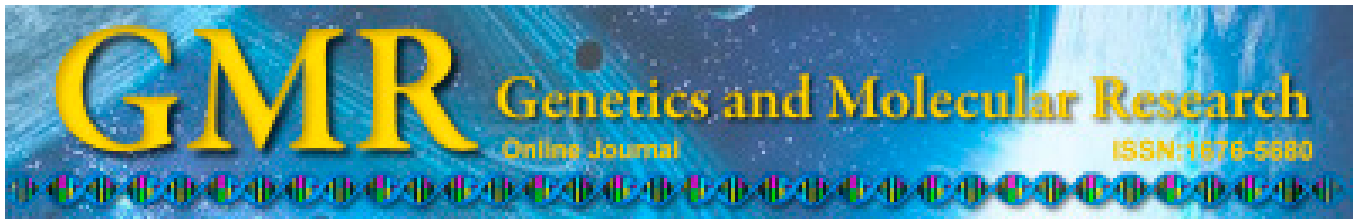

\title{
Genetic diversity of Ceratoides arborescens, a species endemic to China, detected by inter- simple sequence repeat (ISSR)
}

\author{
P.C. Wang ${ }^{1}$, L.L. Zhao ${ }^{2}$, B.T. Mo ${ }^{1}$, Y. Zhang ${ }^{1}$, J. Chen ${ }^{1}$ and L.B. Wang ${ }^{3}$ \\ ${ }^{1}$ Guizhou Institute of Prataculture, Guiyang, China \\ ${ }^{2}$ College of Animal Science, Guizhou University, Guiyang, China \\ ${ }^{3}$ Research Institute of Forestry, Chinese Academy Forestry, Beijing, China \\ Corresponding author: L.B. Wang \\ E-mail: wlibing@163.com
}

Genet. Mol. Res. 14 (2): 5658-5666 (2015)

Received August 28, 2014

Accepted January 13, 2015

Published May 25, 2015

DOI http://dx.doi.org/10.4238/2015.May.25.18

\begin{abstract}
In order to investigate genetic diversity and population structure of Ceratoides arborescens, six populations were selected from different steppe types in Inner Mongolia grasslands of China. Intersimple sequence repeat (ISSR) markers were used to assess the genetic diversity within and among natural populations of $C$. arborescens. Thirteen ISSR primers generated 154 discernible DNA bands, of which $151(98.05 \%)$ were polymorphic. High genetic diversity was detected at the species level [percentage of polymorphic loci (PPB) $=98.05 \% ; H$ $=0.2984 ; I=0.4557]$, whereas, relatively low genetic diversity existed within populations $(\mathrm{PPB}=80.62 \% ; H=0.2675 ; I=0.4031)$. Analysis of molecular variance showed that variation existed mainly within populations $(73.25 \%)$ rather than among populations $(26.75 \%)$, which was in line with the high level of gene flow $\left(N_{\mathrm{m}}=4.3332\right)$. The Mantel test found no significant correlation between genetic distance and geographic distance $(r=0.7522, \mathrm{P}<0.05)$. Six populations were clustered into two main groups, a desert steppe group and a typical steppe group.
\end{abstract}

Key words: Ceratoides arborescens; Inter-simple sequence repeat (ISSR); Genetic diversity; Conservation implications 


\section{INTRODUCTION}

The analysis of genetic diversity is a key element for the study of biodiversity, ecosystem functioning, and the consequences of anthropogenic impact on natural systems ( $\mathrm{Li}$ et al., 2012; Wang et al., 2012; Yang et al., 2014). Genetic diversity plays an important role in the survival and adaptability of a species, and it is largely attributed to several life history traits, such as geographic range, seed dispersal mechanism, mating system, life form, and taxonomic status (Zhang et al., 2006; Tian et al., 2012; Zhao et al., 2012; Liu et al., 2013; Ghaffari et al., 2014). Compared to widespread species, many endemic and rare species usually show low levels of genetic diversity because of their habitat fragmentation (Yang et al., 2012; Sow et al., 2014). The loss of genetic variability usually has deleterious effects on the species response to natural selection and may threaten the survival of the species or populations (Jugran et al., 2011; Teixeira et al., 2014). Thus, an accurate estimate of genetic diversity of a species is important for the conservation and sustainable exploitation of the species.

Ceratoides arborescens (Chenopodiaceae), a plant species endemic to China, is widely distributed in northwest China, especially in the typical steppes and desert steppes of Inner Mongolia. In addition, it often occurs on farmlands alongside the annual and perennial crops, at altitudes ranging from 800 to $1800 \mathrm{~m}$ and the rainfall from 200 to $500 \mathrm{~mm}$ per annum (Yi et al., 2004; Tong et al., 2010; Dong et al., 2012). As a multipurpose species of great economic and environmental value, it has been used for grassland improvement because of its high nutritional value and high stress tolerance (Yi et al., 2004; Han and Yi, 2008; Tong et al., 2010). However, due to habitat degradation and overgrazing, the species exhibits a fragmented distribution pattern. Conservation and rational use of this species are thus of primary importance. Selection and assessment of genotypes could facilitate breeding processes by separating populations with genetic similarity.

Previous studies have focused on morphology and anatomy (Bai et al., 1998; Liu et al., 2007; Zhou et al., 2007), reproductive biology (Han and Yi, 2008; Lu et al., 2009), and population ecology (Xie et al., 2007). No study has investigated the species' genetic diversity and population structure, although such information is essential for the formulation of effective conservation and sustainable exploitation strategies. Inter simple sequence repeat (ISSR) method has been applied to assess genetic diversity especially in plants with no or only few available specific primers, such as Dactylis glomerata (Madesis et al., 2014) and Brachiaria ruziziensis (both from Poaceae) (Azevedo et al., 2011). The objective of this study is to evaluate genetic diversity and population structure within and among the populations of $C$. arborescens in Inner Mongolia grasslands of China, in order to improve the management of genetic resources.

\section{MATERIAL AND METHODS}

\section{Study sites and sampling}

A total of 120 individuals of $C$. arborescens were collected from six natural populations in the middle and eastern regions of Inner Mongolia, in the area of the typical geographical distribution of the species (Figure 1, Table 1). Fresh tender leaves were collected randomly from 20 mature individuals in each population. The distances between sampled individuals varied between 30 and $50 \mathrm{~m}$, depending on the population size. The sampled leaves were kept 
at $4^{\circ} \mathrm{C}$ in sealed bags and stored at $-70^{\circ} \mathrm{C}$ at the Inner Mongolia Agriculture University until DNA extraction.

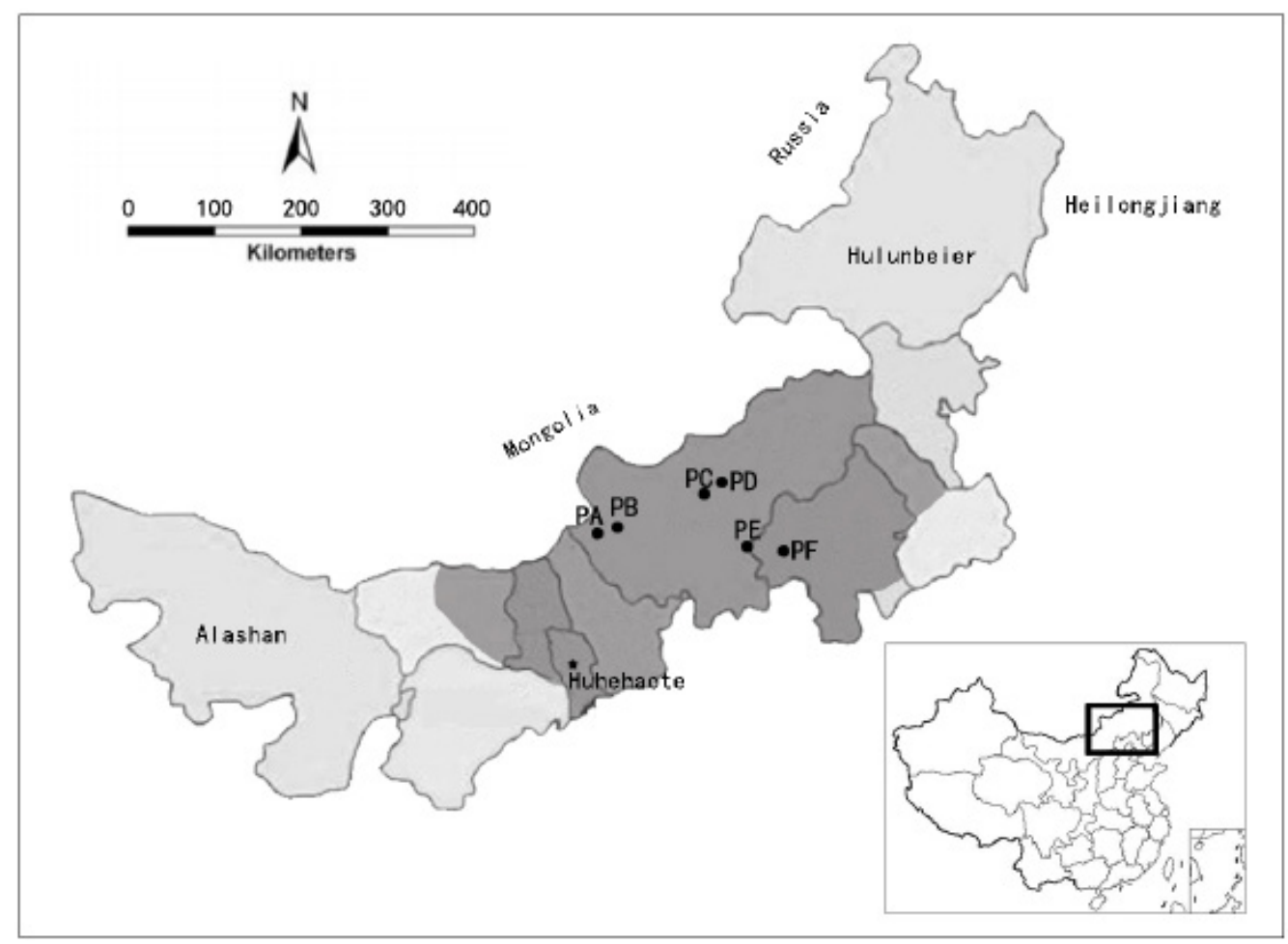

Figure 1. Map of the six sample populations of Ceratoides arborescens in Inner Mongolia grassland of China.

Table 1. Populations of Ceratoides arborescens examined in the ISSR analysis.

\begin{tabular}{llcccc}
\hline $\begin{array}{l}\text { Population } \\
\text { code }\end{array}$ & Place of collection & Elevation $(\mathrm{m})$ & Geographic coordinates & Vegetation type & $\begin{array}{c}\text { Sample size } \\
\text { (Number of clumps) }\end{array}$ \\
\hline PA & West Baiyinxile, Siziwang, Wulanchabu & 1397 & $42^{\circ} 10^{\prime} 37^{\prime \prime} \mathrm{N}, 112^{\circ} 10^{\prime} 38^{\prime \prime} \mathrm{E}$ & Desert steppe & $>300$ \\
PB & East Baiyinxile, Siziwang, Wulanchabu & 1446 & $42^{\circ} 08^{\prime} 35^{\prime \prime} \mathrm{N}, 112^{\circ} 11^{\prime} 38^{\prime \prime} \mathrm{E}$ & Desert steppe & $>300$ \\
PC & Southern suburbs, Xilinhaote, Xilinguole & 1085 & $43^{\circ} 48^{\prime} 53^{\prime \prime} \mathrm{N}, 116^{\circ} 06^{\prime} 01^{\prime \prime E}$ & Typical steppe & 267 \\
PD & Southwestern suburbs, Xilinhaote, Xilinguole & 1190 & $43^{\circ} 47^{\prime} 21^{\prime \prime N}, 116^{\circ} 07^{\prime} 52^{\prime \prime} \mathrm{E}$ & Typical steppe & 179 \\
PE & Kangjiaying, Jingpeng, Keshiketeng & 1250 & $43^{\circ} 19^{\prime} 06^{\prime \prime} \mathrm{N}, 117^{\circ} 32^{\prime} 58^{\prime \prime} \mathrm{E}$ & Typical steppe & 135 \\
PF & Sizhangfang, Wudan, Wengniute & 704 & $43^{\circ} 04^{\prime} 31^{\prime \prime N}, 118^{\circ} 53^{\prime} 14^{\prime \prime} \mathrm{E}$ & Typical steppe & 69 \\
\hline
\end{tabular}

\section{DNA extraction and ISSR-PCR amplification}

DNA was extracted using a modified CTAB method (Zhang et al., 2006) and dissolved in $1 \mathrm{X}$ TE buffer for subsequent use. DNA quality and quantification were estimated by spectrophotometer analysis (Eppendorf BioPhotometer, Eppendorf, Hamburg, Germany). ISSR-PCR amplifications were performed in a GeneAmp PCR System 9700 
DNA Thermal Cycler (PerkinElmer, Waltham, MA, USA) with cycling profile: 3 min at $94^{\circ} \mathrm{C}$, followed by 35 cycles of $30 \mathrm{~s}$ at $94^{\circ} \mathrm{C}, 45 \mathrm{~s}$ at $48^{\circ} \mathrm{C}$, and $1.5 \mathrm{~min}$ at $72^{\circ} \mathrm{C}$, and ending with $10 \mathrm{~min}$ at $72^{\circ} \mathrm{C}$. One hundred primers (Biotechnology Laboratory, Inner Mongolia Agriculture University) were screened initially to identify the well-amplified polymorphic bands among the populations. Of the 100 primers tested, 13 produced bright, clear, and reproducible bands. These primers were selected for further study of the $120 \mathrm{C}$. arborescens individuals.

PCR was carried out in a total volume of $20 \mu \mathrm{L}$, which included 50 ng template DNA, $2 \mu \mathrm{L} 10 \mathrm{X}$ PCR buffer ( $\mathrm{Mg}^{2+}$ Plus), $2 \mu \mathrm{L} 25 \mathrm{mM} \mathrm{MgCl}, 1.0 \mu \mathrm{L} 2.5 \mathrm{mM}$ dNTPs Mixture, $1.0 \mathrm{U}$ Taq polymerase (TaKaRa Bio, Dalian, China), and $0.4 \mu \mathrm{M}$ of each primer (Shanghai Sangon Bio, Shanghai, China). Amplification products, along with a GeneRuler100 ladder (Fermentas, Burlington, Canada), were separated via electrophoresis on $1.5 \%(\mathrm{w} / \mathrm{v})$ agarose gels with $0.5 \mathrm{X}$ TBE buffer at $120 \mathrm{~V}$ for $3-4 \mathrm{~h}$ and stained with $0.1 \mathrm{mg} / \mu \mathrm{L}$ ethidium bromide. They were then photographed with an Epson digital still AF camera (Epson, Suwa, Japan). Negative controls, which lacked template DNA, were also included in each PCR set to test for possible contamination.

\section{Genetic diversity analysis}

The experiment was repeated three times and only clear and reproducible bands were recorded. They were scored as 1 for presence or 0 for absence for each sample, and a matrix of different ISSR phenotypes was assembled for statistical analysis. These genetic indexes including the observed number of alleles, effective number of alleles, percentage of polymorphic loci (PPB), Shannon index $(I)$ of diversity, and Nei's population differentiation $\left(G_{\mathrm{ST}}\right)$ were calculated using the POPGENE version 1.32 software (Peakall and Smouse, 2006). A dendrogram based on Nei's genetic distance was constructed by cluster analysis using an unweighted pair-group method with arithmetic averages (UPGMA) implemented in MEGA program version 3.1 (Kumar et al., 2004). Molecular analysis of variance (AMOVA) was performed to analyze genetic distance among populations using ARLEQUIN (Excoffier et al., 2005). In addition, the Mantel test was performed using Mantel 2.0 to determine the correlation between inter-population genetic and geographic distance matrices (Mantel, 1967).

\section{RESULTS}

\section{Genetic diversity}

The thirteen selected primers generated 154 bands, corresponding to an average of 11.9 bands per primer (Table 2). Of the 154 bands, 151 were polymorphic $(98.05 \%)$ at the species level. The genetic diversity parameters of $C$. arborescens populations are shown in Table 3. Nei's gene diversity was estimated to be 0.2675 at the population level and 0.2984 at the species level. $I$ was 0.4031 (at the population level) and 0.4557 (at the species level). Among our six populations, the highest level of variability was found in population of west Baiyinxile (PA) $(\mathrm{PPB}=87.66 \% ; H=0.2765 ; I=0.4206)$ and the lowest level in population of Sizhangfang $(\mathrm{PF})(\mathrm{PPB}=74.68 \% ; H=0.2545 ; I=0.3810)$. 
Table 2. Sequences and numbers of bands for 13 primers.

\begin{tabular}{|c|c|c|c|c|}
\hline Primer code & Sequence $\left(5^{\prime}-3^{\prime}\right)$ & Total bands & Polymorphic bands & PPB (\%) \\
\hline UBC807 & $(\mathrm{AG})_{8} \mathrm{~T}$ & 14 & 13 & 92.9 \\
\hline UBC 808 & $(\mathrm{AG}){ }_{8} \mathrm{C}$ & 15 & 14 & 93.3 \\
\hline UBC810 & $(\mathrm{GA})_{8}^{0} \mathrm{~T}$ & 14 & 14 & 100.0 \\
\hline UBC812 & $(\mathrm{GA})_{8} \mathrm{~A}$ & 14 & 14 & 100.0 \\
\hline UBC817 & $(\mathrm{CA})_{8}^{8} \mathrm{~A}$ & 8 & 8 & 100.0 \\
\hline UBC818 & $(\mathrm{CA})_{8}^{\circ} \mathrm{G}$ & 11 & 11 & 100.0 \\
\hline UBC 820 & $(\mathrm{GT})_{8}^{8} \mathrm{C}$ & 9 & 8 & 88.9 \\
\hline UBC825 & $(\mathrm{AC})_{8} \mathrm{~T}$ & 13 & 13 & 100.0 \\
\hline UBC827 & $(\mathrm{AC})_{8}^{\circ} \mathrm{G}$ & 10 & 10 & 100.0 \\
\hline UBC840 & $(\mathrm{GA})_{8}^{8} \mathrm{YT}$ & 15 & 15 & 100.0 \\
\hline UBC856 & $(\mathrm{AC})_{8}^{\circ} \mathrm{YA}$ & 11 & 11 & 100.0 \\
\hline UBC857 & $(\mathrm{AC})_{8}^{0} \mathrm{YG}$ & 11 & 11 & 100.0 \\
\hline UBC866 & $(\mathrm{CTC})_{6}$ & 9 & 9 & 100.0 \\
\hline Total & & 154 & 151 & 98.05 \\
\hline Mean & & 11.9 & 11.6 & \\
\hline
\end{tabular}

$\mathrm{Y}=(\mathrm{C}, \mathrm{T})$.

Table 3. Genetic diversity of Ceratoides arborescens detected by ISSR analysis.

\begin{tabular}{lccccc}
\hline Populations & $N_{\mathrm{A}}$ & $N_{\mathrm{E}}$ & $H$ & $I$ & PPB (\%) \\
\hline PA & 1.8766 & 1.4622 & 0.2765 & 0.4206 & 87.66 \\
PB & 1.8701 & 1.4638 & 0.2753 & 0.4176 & 87.01 \\
PC & 1.7792 & 1.4511 & 0.2646 & 0.4060 & 77.92 \\
PD & 1.7922 & 1.4664 & 0.2708 & 0.3954 & 79.22 \\
PE & 1.7727 & 1.4455 & 0.2633 & 0.3810 & 74.68 \\
PF & 1.7468 & 1.4402 & 0.2545 & 0.4031 & 80.62 \\
Mean value & 1.8063 & 1.4549 & 0.2675 & 0.4557 & 98.05 \\
Species level & 1.9805 & 1.5002 & 0.2984 & & \\
\hline
\end{tabular}

$N_{\mathrm{A}}=$ observed number of alleles, $N_{\mathrm{E}}=$ effective number of alleles, $H=$ Nei's gene diversity, $I=$ Shannon's information index, $\mathrm{PPB}=$ percentage of polymorphic loci.

\section{Genetic differentiation among populations}

The genetic differentiation among the populations assessed by gene differentiation coefficient $\left(G_{\mathrm{ST}}\right)$ was 0.1154 , which indicated that $11.54 \%$ of the total genetic variation was among the populations. A similar level of genetic differentiation among the populations was obtained from AMOVA, $13.21 \%$ among the populations and $86.79 \%$ within populations. The genetic differentiation values of $C$. arborescens populations were highly significant $(\mathrm{P}<$ $0.001)$ and $F_{\mathrm{ST}}$ was 0.132 (Table 4$)$. The level of gene flow $\left(N_{\mathrm{m}}\right)$ was 4.3332 , which indicated high level of gene exchange among the populations.

\begin{tabular}{|c|c|c|c|c|c|c|c|}
\hline Source of variation & d.f. & $\begin{array}{l}\text { Sum of } \\
\text { squares }\end{array}$ & $\begin{array}{c}\text { Mean } \\
\text { squares }\end{array}$ & $\begin{array}{c}\text { Variance } \\
\text { components }\end{array}$ & $\begin{array}{l}\text { Percentage of } \\
\text { variation }(\%)\end{array}$ & $\begin{array}{c}\text { Fixtion } \\
\text { index }\left(F_{\mathrm{ST}}\right)\end{array}$ & $P$ value \\
\hline Among populations & 5 & 447.217 & 89.443 & 3.366 & 13.21 & 0.132 & $<0.001$ \\
\hline Within populations & 114 & 2521.000 & 22.114 & 22.114 & 86.79 & & $<0.001$ \\
\hline Sum & 119 & 2968.217 & 111.557 & 25.480 & 100.00 & & \\
\hline
\end{tabular}




\section{Genetic relationship}

The UPGMA tree (Figure 2), inferred from the Nei's genetic distance for C. arborescens, resolved the six populations into two clades: a desert steppe group and a typical steppe group. The former included populations PA and of East Baiyinxile (PB), whereas populations of southern suburbs (PC), southwestern suburbs (PD), Kangjiaying (PE), and PF made the latter group. This topology was consistent with the geographic distribution of these populations, indicating a possible correlation. Nei's unbiased genetic distances among the populations were calculated based on 151 markers scored. Values ranged from 0.0283 (PA vs PB) to 0.0674 (PA vs PE) (Table 5). The Mantel test identified a significant correlation between geographic and genetic distances among the populations $(r=0.7522, \mathrm{P}<0.05)$.

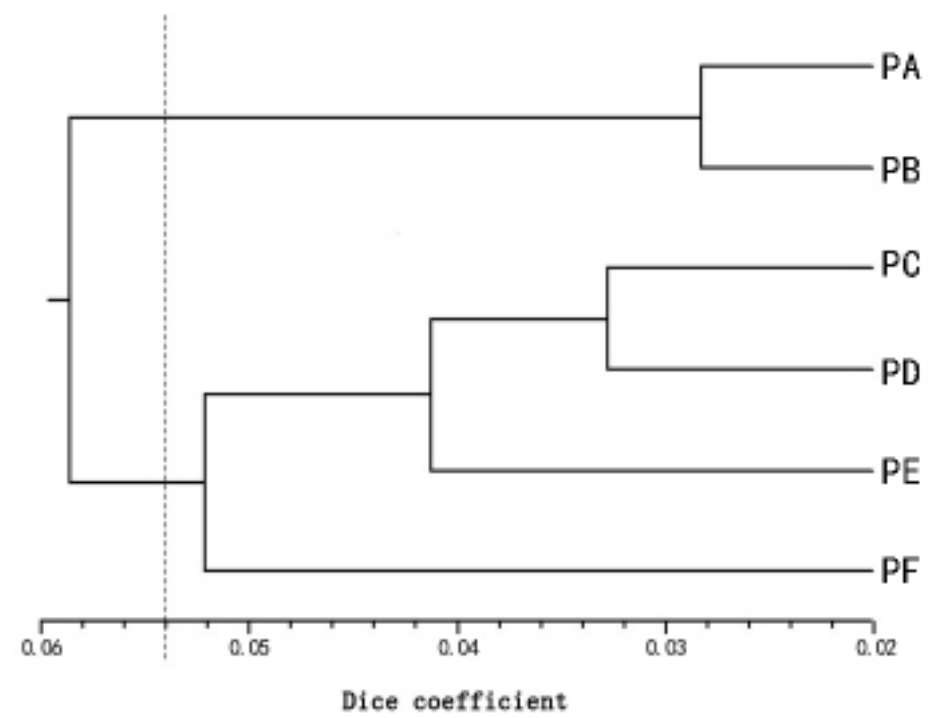

Figure 2. UPGMA dendrogram based on Nei's genetic distances among six populations of Ceratoides arborescens.

Table 5. Nei's unbiased genetic identity (above diagonal) and genetic distance (below diagonal) among Ceratoides arborescens populations.

\begin{tabular}{|c|c|c|c|c|c|c|}
\hline Population & PA & $\mathrm{PB}$ & $\mathrm{PC}$ & PD & $\mathrm{PE}$ & $\mathrm{PF}$ \\
\hline $\mathrm{PA}$ & - & 0.9721 & 0.9562 & 0.9420 & 0.9348 & 0.9376 \\
\hline PB & 0.0283 & - & 0.9501 & 0.9423 & 0.9361 & 0.9365 \\
\hline $\mathrm{PC}$ & 0.0447 & 0.0512 & - & 0.9678 & 0.9611 & 0.9459 \\
\hline PD & 0.0598 & 0.0594 & 0.0328 & - & 0.9580 & 0.9526 \\
\hline PE & 0.0674 & 0.0660 & 0.0397 & 0.0429 & - & 0.9491 \\
\hline PF & 0.0644 & 0.0656 & 0.0556 & 0.0486 & 0.0522 & - \\
\hline
\end{tabular}

\section{DISCUSSION}

\section{Genetic diversity}

Previous studies have shown that endemic species and species with narrow distribu- 
tion usually show lower levels of genetic diversity than widespread species (Tanahara and Maki, 2010; Chen et al., 2013; Duan et al., 2013; Nguyen et al., 2013; Aoki et al., 2014). However, C. arborescens was found to possess an unexpectedly high rate of genetic diversity (Table 3), indicating the species ability to adapt to varying environmental conditions. As a long-lived perennial plant, $C$. arborescens is widely distributed in the mid-eastern Inner Mongolia of China. To adapt to ecologically diverse habitats, it probably adopts outcrossing breeding systems, the wind-pollinated and wind-dispersed system. All these traits together have probably resulted in its presently high level of genetic diversity at the species level.

Moreover, many researchers have considered that habitat fragmentation, location, and population size have high impact on genetic diversity within populations (Feng et al., 2006; Arunkumar et al., 2012; Liu et al., 2013; Ghaffari et al., 2014). In the present study, the desert steppe group (PA, $\mathrm{PB}$ ) exhibits a higher degree of genetic diversity than the typical steppe group (PC, PD, PE, and PF), This result was consistent with population size, suggesting that fragmented habitats, migration (decreased or absent) between populations, and genetic drift have probably contributed to the loss of diversity in the populations, especially in PF.

\section{Genetic structure}

Population genetic structure reflects the interactions among species' long-term evolutionary history (e.g., habitat fragmentation, population specialization), mutation, recombination, genetic drift, breeding system, gene flow, and natural selection (Adoukonou-Sagbadja et al., 2007). In this study, genetic differentiation was consistent with the pattern of strong variation within populations and weak variation among populations (Table 4). The genetic differentiation was low $\left(G_{\mathrm{ST}}=0.1154\right)$ and gene flow $\left(N_{\mathrm{m}}=4.333\right)$ was high among $C$. arborescens populations. Typically, $N_{\mathrm{m}}>1$ indicates weak differential selection (Rossi et al., 2009; Oja and Talve, 2012; Munthali et al., 2013). Therefore, the present low level of genetic differentiation among populations could be largely attributed to several factors. First, the mode of pollen and seed dispersal, which determines the $N_{\mathrm{m}}$ among populations (Li et al., 2009a; Bellucci et al., 2011; Nestmann et al., 2011; Wang and Li, 2011), can facilitate $N_{\mathrm{m}}$ among populations, minimizing the population differentiation. Many studies have demonstrated that wind-pollinated and wind-dispersed species exhibit low levels of genetic differentiation (Li et al., 2009b; Adamski et al., 2012; Thomas et al., 2012), approaching the levels observed in C. arborescens. Second, genetic diversity may be influenced by geographic distances, especially longitudinal differences, as revealed by the Mantel test. These are expected to result in relatively low levels of genetic differentiation among C. arborescens populations due to frequent large-scale $N_{\mathrm{m}}$.

\section{Implications for future conservation}

This study has implications for the use and conservation of this species through its potential role for multiple uses in the changing grassland environment of Inner Mongolia. Information obtained from this study provides valuable baseline data on the population genetics of $C$. arborescens, which suggest that the higher percentage of total variation is still harbored within population and indicates that in the Inner Mongolia grassland environment, $C$. arborescens is not genetically depauperate. Recent human intervention through overgrazing may be the main factor responsible for the fragmented status of this species. Therefore, habitat sites protection of $C$. arborescens should be concentrated on restoring the natural ecological bal- 
ance through reducing livestock grazing.

\title{
ACKNOWLEDGMENTS
}

\author{
Research supported by the National Natural Science Foundation of China (Grant \\ \#31260572, \#71263012, and \#41401069).
}

\section{REFERENCES}

Adamski DJ, Dudley NS, Morden CW and Borthakur D (2012). Genetic differentiation and diversity of Acacia koa populations in the Hawaiian Islands. Plant Species Biol. 27: 181-190.

Adoukonou-Sagbadja H, Wagner C, Dansi A, Ahlemeyer J, et al. (2007). Genetic diversity and population differentiation of traditional fonio millet (Digitaria spp.) landraces from different agro-ecological zones of West Africa. Theor. Appl. Genet. 115: 917-931.

Aoki K, Ueno S, Kamijo T, Setoguchi H, et al. (2014). Genetic differentiation and genetic diversity of Castanopsis (Fagaceae), the dominant tree species in Japanese broadleaved evergreen forests, revealed by analysis of ESTassociated microsatellites. PloS One 9: e87429.

Arunkumar KP, Sahu AK, Mohanty AR, Awasthi AK, et al. (2012). Genetic diversity and population structure of Indian golden silkmoth (Antheraea assama). PloS One 7: e43716.

Azevedo ALS, Costa PP, Machado MA, de Paula CMP, et al. (2011). High degree of genetic diversity among genotypes of the forage grass Brachiaria ruziziensis (Poaceae) detected with ISSR markers. Genet. Mol. Res. 10: 3530-3538.

Bai YG, Booth DT and Romo JT (1998). Winterfat (Eurotia lanata (Pursh) Moq.) seedbed ecology: low temperature exotherms and cold hardiness in hydrated seeds as influenced by imbibition temperature. Ann. Bot. 81: 595-602.

Bellucci E, Nanni L, Bitocchi E, Rossi M, et al. (2011). Genetic diversity and geographic differentiation in the alternative legume Tripodion tetraphyllum (L.) Fourr. in North African populations. Plant Biol. 13: 381-390.

Chen SY, Zhang XQ, Ma X and Huang LK (2013). Assessment of genetic diversity and differentiation of Elymus nutans indigenous to Qinghai-Tibet Plateau using simple sequence repeats markers. Can. J. Plant. Sci. 93: 1089-1096.

Dong J, Wang XM, Wang K, Wang Z, et al. (2012). Isolation and characterization of a gene encoding an ethylene responsive factor protein from Ceratoides arborescens. Mol. Biol. Rep. 39: 1349-1357.

Duan Y, Wu YQ, Luo LZ, Miao J, et al. (2013). Genetic diversity and population structure of Sitodiplosis mosellana in northern China. PloS One 8: e78415.

Excoffier L, Laval G and Schneider S (2005). ARLEQUIN: an integrated software package for population genetics data analysis. Evol. Bioinform. Online 1: 47-50.

Feng ZY, Zhang LL, Zhang YZ and Ling HQ (2006). Genetic diversity and geographical differentiation of cultivated sixrowed naked barley landraces from the Qinghai-Tibet plateau of China detected by SSR analysis. Genet. Mol. Biol. 29: $330-338$

Ghaffari P, Talebi R and Keshavarzi F (2014). Genetic diversity and geographical differentiation of Iranian landrace, cultivars, and exotic chickpea lines as revealed by morphological and microsatellite markers. Physiol. Mol. Biol. Plants 20: 225-233.

Han ZL and Yi J (2008). Study on the dynamic changes of endogenous hormones in Ceratoides arborescens during seed development. Seed 29: 3-9.

Jugran A, Bhatt ID, Rawat S, Giri L, et al. (2011). Genetic diversity and differentiation in Hedychium spicatum, a valuable medicinal plant of Indian Himalaya. Biochem. Genet. 49: 806-818.

Kumar S, Tamura K and Nei M (2004). MEGA3: integrated software for molecular evolutionary genetics analysis and sequence alignment. Brief. Bioinform. 5: 150-163.

Li JM, Jin ZX and Tan T (2012). Genetic diversity and differentiation of Sinocalycanthus chinensis populations revealed by chloroplast microsatellite (cpSSRs) markers. Biochem. Syst. Ecol. 41: 48-54.

Li MM, Cai YL, Qian ZQ and Zhao GF (2009a). Genetic diversity and differentiation in Chinese sour cherry Prunus pseudocerasus Lindl., and its implications for conservation. Genet. Resour. Crop Evol. 56: 455-464.

Li XH, Wang KJ and Jia JZ (2009b). Genetic diversity and differentiation of Chinese wild soybean germplasm (G. soja Sieb. \& Zucc.) in geographical scale revealed by SSR markers. Plant Breed. 128: 658-664.

Liu J, Jia RF, He X and Yi J (2007). Characteristic of Ceratoides arboresens pollen germination and effects of different pollination modes on seed setting. Seed 26: 5-9.

Liu J, Sun HG, Jiang JM, Shao WH, et al. (2013). Genetic diversity of natural populations of Machilus thunbergii, an 
endangered tree species in eastern China, determined with ISSR analysis. Genet. Mol. Res. 12: 3689-3697.

Lu LN, Li QF, He X and Yi J (2009). Flowering phenology of Ceratoides arborescens. Acta Bot. Boreali-Occidentalia Sin. 29: 1176-1181.

Madesis P, Abraham EM, Kalivas A, Ganopoulos I, et al. (2014). Genetic diversity and structure of natural Dactylis glomerata L. populations revealed by morphological and microsatellite-based (SSR/ISSR) markers. Genet. Mol. Res. 13: 4226-4240.

Mantel N (1967). The detection of disease clustering and a generalized regression approach. Cancer Res. 27: 209-220.

Munthali CRY, Chirwa PW, Changadeya WJ and Akinnifesi FK (2013). Genetic differentiation and diversity of Adansonia digitata L. (baobab) in Malawi using microsatellite markers. Agroforest. Syst. 87: 117-130.

Nestmann S, Sretenovic Rajicic T, Dehmer KJ, Fischer M, et al. (2011). Plant species diversity and composition of experimental grasslands affect genetic differentiation of Lolium perenne populations. Mol. Ecol. 20: 2188-2203.

Nguyen HTT, Choi KS and Park SJ (2013). Genetic diversity and differentiation of a narrowly distributed and endemic species, Aster spathulifolius maxim (Asteraceae), revealed with inter simple sequence repeat markers. J. Korean Soc. Appl. Biol. Chem. 56: 255-262.

Oja T and Talve T (2012). Genetic diversity and differentiation in six species of the genus Rhinanthus (Orobanchaceae). Plant Syst. Evol. 298: 901-911.

Peakall R and Smouse PE (2006). GENALEX 6: genetic analysis in Excel. Population genetic software for teaching and research. Mol. Ecol. Notes 6: 288-295.

Rossi AAB, de Oliveira LO, Venturini BA and dos Santos Silva R (2009). Genetic diversity and geographic differentiation of disjunct Atlantic and Amazonian populations of Psychotria ipecacuanha (Rubiaceae). Genetica 136: 57-67.

Sow M, Ndjiondjop MN, Sido A, Mariac C, et al. (2014). Genetic diversity, population structure and differentiation of rice species from Niger and their potential for rice genetic resources conservation and enhancement. Genet. Resour. Crop Evol. 61: 199-213.

Tanahara A and Maki M (2010). Genetic diversity and population genetic differentiation in the endangered annual weed, Bidens cernua (Compositae), and two common congeners in Japan. Weed Biol. Manag. 10: 113-119.

Teixeira H, Rodríguez-Echeverría S and Nabais C (2014). Genetic diversity and differentiation of Juniperus thurifera in Spain and Morocco as determined by SSR. PloS One 9: e88996.

Thomas E, van Zonneveld M, Loo J, Hodgkin T, et al. (2012). Present spatial diversity patterns of Theobroma cacao L. in the Neotropics reflect genetic differentiation in Pleistocene refugia followed by human-influenced dispersal. PloS One 7: e47676.

Tian B, Yang HQ, Wong KM, Liu AZ, et al. (2012). ISSR analysis shows low genetic diversity versus high genetic differentiation for giant bamboo, Dendrocalamus giganteus (Poaceae: Bambusoideae), in China populations. Genet. Resour. Crop Evol. 59: 901-908.

Tong LR, Han JG and Dong KH (2010). Increasing storability of Ceratoides arborescens seeds in ultradry storage. Afr. J. Biotechnol. 9: 4601-4605.

Wang KJ and Li XH (2011). Genetic differentiation and diversity of phenotypic characters in Chinese wild soybean (Glycine soja Sieb. et Zucc.) revealed by nuclear SSR markers and the implication for intraspecies phylogenic relationship of characters. Genet. Resour. Crop Evol. 58: 209-223.

Wang YL, Qin YY, Du Z and Yan GQ (2012). Genetic diversity and differentiation of the endangered tree Elaeagnus mollis Diels (Elaeagnus L.) as revealed by Simple Sequence Repeat (SSR) markers. Biochem. Syst. Ecol. 40: 25-33.

Xie JB, Liu T, Wei P, Jia YM, et al. (2007). Ecological application of wavelet analysis in the scaling of spatial distribution patterns of Ceratoides ewersmanniana. Acta Ecol. Sin. 27: 2704-2714.

Yang HQ, An MY, Gu ZJ and Tian B (2012). Genetic diversity and differentiation of Dendrocalamus membranaceus (Poaceae: Bambusoideae), a declining bamboo species in Yunnan, China, as based on inter-simple sequence repeat (ISSR) analysis. Int. J. Mol. Sci. 13: 4446-4457.

Yang Q, Fu Y, Wang YQ, Wang Y, et al. (2014). Genetic diversity and differentiation in the critically endangered orchid (Amitostigma hemipilioides): implications for conservation. Plant Syst. Evol. 300: 871-879.

Yi J, Wang XM, Wuren QMG and Gu AL (2004). Studies on seed physiological characteristics of Ceratoides (Tourn.) Gagnebin - The correlation between the nutritive composition, the hormone and seed vigor. Seed 23: 3-9.

Zhang L, Li QJ, Li HT, Chen J, et al. (2006). Genetic diversity and geographic differentiation in Tacca chantrieri (Taccaceae): an autonomous selfing plant with showy floral display. Ann. Bot. 98: 449-457.

Zhao XF, Ma YP, Sun WB, Wen XY, et al. (2012). High genetic diversity and low differentiation of Michelia coriacea (Magnoliaceae), a critically endangered endemic in southeast Yunnan, China. Int. J. Mol. Sci. 13: 4396-4411.

Zhou LJ, Pei KQ, Zhou B and Ma KP (2007). A molecular approach to species identification of Chenopodiaceae pollen grains in surface soil. Am. J. Bot. 94: 477-481. 